\title{
Biofabrication of a Hyaluronan/Bacterial Cellulose Composite Nanofibril by Secretion from Engineered Gluconacetobacter
}

\author{
Ryo Takahama ${ }^{1}$, Honami Kato ${ }^{1}$, Kenji Tajima $^{2 *}$, Satomi Tagawa ${ }^{3}$ \\ and Tetsuo Kondo ${ }^{1,3 *}$
}

${ }^{1}$ Graduate School of Bioresource and Bioenvironmental Sciences, Kyushu University.

West 5th, 744, Motooka, Nishi-ku, Fukuoka 819-0395, Japan.

${ }^{2}$ Faculty of Engineering, Hokkaido University, N13W8, Kita-ku, Sapporo 060-8628, Japan.

${ }^{3}$ Faculty of Agriculture, Kyushu University, West 5th, 744, Motooka, Nishi-ku, Fukuoka 8190395, Japan.

Ryo Takahama (takahama-bio@agr.kyushu-u.ac.jp)

Honami Kato (katohonami1358@icloud.com)

Kenji Tajima (ktajima@eng.hokudai.ac.jp): ORCID: 0000-0002-3238-813X

Satomi Tagawa (tagawa3103@gmail.com)

Tetsuo Kondo (tekondo@agr.kyushu-u.ac.jp): ORCID: 0000-0003-4366-2955

*Corresponding author: Tetsuo Kondo

Please address all correspondence to:

tekondo@agr.kyushu-u.ac.jp; Tel./Fax. No.: +81-92-802-4668

* Co-corresponding author: equally contributed): Kenji Tajima 


\section{SUPPORTING INFORMATION}

\section{Materials and Methods}

\section{Chemicals, Enzymes, and Bacteria}

EcoRI, SaI and Escherichia coli (E. coli) HST08 were purchased from TaKaRa Bio Inc. (Shiga,

Japan). Glucose was purchased from Sigma-Aldrich (MO, USA) and Bacto yeast extract, peptone, agar and Luria-Bertani (LB) broth Lennox were purchased from Difco Laboratories Inc. (NJ, USA). Disodium hydrogenphosphate heptahydrate $\left(\mathrm{Na}_{2} \mathrm{HPO}_{4} \cdot 7 \mathrm{H}_{2} \mathrm{O}\right)$ was purchased from Nacalai Tesque Inc. (Kyoto, Japan). Citric acid, ampicillin sodium, kanamycin sulfate, glycerol, and lysozyme were purchased from Wako Pure Chemical Industries, Ltd. (Osaka, Japan). Cellulase "ONOZUKA" R-10 was purchased from Yakult Pharmaceutical Industry Co., Ltd. (Tokyo, Japan). Sodium hyaluronate FCH-60 was purchased from Kikkoman Biochemifa Co. (Tokyo, Japan). Hyaluronidase from sheep testes Type II was purchased from Sigma-Aldrich. All other chemicals were of reagent-grade quality or better. Pasteurella multocida ATCC15742, Sinorhizobium meliloti 1021 (Ensifer meliloti) ATCC51124, and Gluconacetobacter hansenii (present name, Komagataeibacter hansenii) ATCC 23769 were purchased from American Type Culture Collection. 


\section{Plasmid Construction}

Plasmids, genes, and primers used in this study are listed in Table S1. PmHAS gene ${ }^{1}$ (pmhas) was amplified by polymerase chain reaction (PCR) from the genomic DNA of Pasteurella multocida (ATCC15742) using $\mathrm{SP}$ (pmhas) and $\mathrm{AP}($ pmhas) as primers. UGD gene (ugd) was amplified from the genomic DNA of Sinorhizobium meliloti $1021^{2,3}$ using $\operatorname{SP}(u g d)$ and $\operatorname{AP}(u g d)$ to produce a ugd fragment, which was accompanied by Trc promoter, lac operator, and the ribosome binding site (RBS) of pTI99 plasmid ${ }^{4}$ on the upstream region. The amplified PCR fragments were purified using a FastGene Gel/PCR Extraction Kit (NIPPON Genetics Co., Ltd). To construct the pTIHA plasmid, PCR fragments of pmhas and ugd were ligated with EcoRI/SaIdigested pTI99 using an In-Fusion HD Cloning Kit (Takara Bio Inc.), followed by cloning using E. coli HST08 Premium Competent Cells (Takara Bio Inc.). PCR for the amplification of pmhas and $u g d$ was conducted using PrimeSTAR GXL DNA Polymerase (Takara Bio Inc.) under the following cycling conditions: $94{ }^{\circ} \mathrm{C}$ for $2 \mathrm{~min}$; then 30 cycles of $98^{\circ} \mathrm{C}$ for $10 \mathrm{~s}, 60^{\circ} \mathrm{C}$ for $15 \mathrm{~s}, 68$ ${ }^{\circ} \mathrm{C}$ for $3 \mathrm{~min}$; and finally $68{ }^{\circ} \mathrm{C}$ for $5 \mathrm{~min}$. KOD One PCR Master Mix (TOYOBO Co., Ltd.) was used for other PCR experiments under the following conditions: $98^{\circ} \mathrm{C}$ for $1 \mathrm{~min}$; seven touchdown 
cycles of $98{ }^{\circ} \mathrm{C}$ for $10 \mathrm{~s}$ and $74{ }^{\circ} \mathrm{C}$ at $-2{ }^{\circ} \mathrm{C} /$ cycle for $5-30 \mathrm{~s}$; then 25 cycles of $98{ }^{\circ} \mathrm{C}$ for $10 \mathrm{~s}, 60$

${ }^{\circ} \mathrm{C}$ for $5 \mathrm{~s}, 68{ }^{\circ} \mathrm{C}$ for $5-30 \mathrm{~s}$; and finally $68{ }^{\circ} \mathrm{C}$ for $1 \mathrm{~min}$. The pTIHA plasmid extracted from recombinant $E$. coli cells was purified carefully to diminish HA hangover in the elution, which otherwise cause a short circuit during electroporation.

A plasmid carrying enhanced green fluorescent protein(egfp)-tagged pmhas (pmhas::egfp), pTIEK-pmhas::egfp was constructed as following: pmhas fragment was amplified using $\mathrm{SP}($ pmhas $)$ and $\mathrm{AP}($ pmhas:: egfp) primers, excluding the termination codon (TAA) at the 3 '

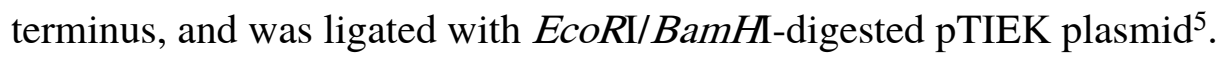

\section{Bacterial Strains and Transformation}

Plasmids were introduced into Gluconacetobacter hansenii ATCC23769 (Gh) by electroporation ${ }^{6}$. Isopropyl- $\beta$-D-thiogalactopyranoside (IPTG) or other inducers were not used in experiments throughout this paper, except for the sample preparation for western blotting. Positive clones were selected from the colonies on the solid medium containing appropriate antibiotics (Ampicillin (Amp), $200 \mu \mathrm{g} / \mathrm{mL}$ ) based on the colony shape and the results of colony-direct $\mathrm{PCR}^{7}$ for each recombinant strain. All colony-direct PCR was conducted using KOD One PCR Master 
Mix -Blue- (TOYOBO Co., Ltd) with the following cycling conditions: $98{ }^{\circ} \mathrm{C}$ for $10 \mathrm{~min} ; 16$ touchdown cycles of $98{ }^{\circ} \mathrm{C}$ for $10 \mathrm{~s}$ and $72{ }^{\circ} \mathrm{C}$ at $-1{ }^{\circ} \mathrm{C} /$ cycle for $5-30 \mathrm{~s}$; then 25 cycles of $98{ }^{\circ} \mathrm{C}$ for $10 \mathrm{~s}, 54{ }^{\circ} \mathrm{C}$ for $5 \mathrm{~s}$, and $68^{\circ} \mathrm{C}$ for $5-30 \mathrm{~s}$; and finally $68^{\circ} \mathrm{C}$ for $5 \mathrm{~min}$. Selected $\mathrm{Gh}$ colonies were transferred to 24 -well plates filled with liquid Hestrin-Schramm (HS) medium ${ }^{8}$ containing antibiotics, then grown statically at $30^{\circ} \mathrm{C}$ for 4 days to confirm the cellulose-producing ability. The selected transformants were transferred to liquid HS medium supplemented with cellulase (cellulase "ONOZUKA" R-10, 0.1\% (w/v)) and appropriate antibiotics, grown at $30{ }^{\circ} \mathrm{C}$ under continuous rotary shaking conditions as seed cultures (125 rpm in shaking flasks or 175 strokes/min in test tubes) until the OD600 reached 0.8-1.0 (24-36 h). The seed culture broth was used as an inoculum for other experiments or preserved at $-80^{\circ} \mathrm{C}$ as glycerol stocks after addition of the same volume of $70 \mathrm{vol} \%$ glycerol (final concentration, $35 \mathrm{vol} \%$ ).

\section{SDS-PAGE and Western Blot Analysis}

A plasmid for expressing C-terminal EGFP-tagged PmHAS, pTIEK-pmhas::egfp, and pTIEK for expressing EGFP as the control were introduced into Gh, respectively. The transformants (Gh(has::egfp) and Gh(egfp)) were prepared as seed cultures, according to the above method. The 
seed cultures were transferred into the HS medium $(100 \mathrm{~mL}$ in $500 \mathrm{~mL}$ volume Sakaguchi (shake)

frask, $1 \%$ inoculation) supplemented with IPTG (final conc. $1 \mathrm{mM}$ ), followed by incubation at 30

${ }^{\circ} \mathrm{C}$ with continuous shaking (125 strokes/min) for $36 \mathrm{~h}$. The cells were collected by centrifugation

$\left(4{ }^{\circ} \mathrm{C}, 6,000 \times \mathrm{g}, 10 \mathrm{~min}\right)$, resuspended in $4{ }^{\circ} \mathrm{C}$ phosphate buffered saline (PBS) and stored at -80

${ }^{\circ} \mathrm{C}$ for more than $12 \mathrm{~h}$. Then the cells in PBS were thawed on ice and crushed with a French press

(5501-M, Otake Ltd., Tokyo, Japan). The debris in the crushed cell suspensions were removed by

centrifugation $\left(4^{\circ} \mathrm{C}, 12,000 \times \mathrm{g}, 30 \mathrm{~min}\right)$. The supernatants were collected as the crude lysates

(CLs). CLs were further separated by ultracentrifugation $\left(4{ }^{\circ} \mathrm{C}, 132,000 \times \mathrm{g}\right.$, $60 \mathrm{~min}$, with Optima

MAX Ultracentrifuge, Beckman Coulter Inc., CA, USA). The supernatants were carefully

collected as the soluble fractions (SFs). The intermediate fractions were removed, and the

precipitates were suspended in $50 \mathrm{mM}$ sodium phosphate buffer $\left(4^{\circ} \mathrm{C}\right)$ as the membrane fractions

$(\mathrm{MFs})^{5}$. The above three fractions for each Gh transformants were analyzed by SDS-PAGE and western blot analysis using an anti-GFP antibody (primary antibody: Anti-GFP pAB, MBL CO., LTD, Tokyo, Japan; secondary antibody: Goat Anti-Rabbit IgG (H\&L)-ARP conjugate, BIORAD, CA, USA). 


\section{Growth Experiments}

Growth experiments using HS medium supplemented with $0.1 \%(\mathrm{w} / \mathrm{v})$ cellulase and antibiotics $(50 \mathrm{~mL})$ were performed in 300-mL shaking Erlenmeyer flasks with baffles under continuous rotary shaking conditions $(125 \mathrm{rpm})$. Culture $(500 \mu \mathrm{L})$ was inoculated into the medium $(50 \mathrm{~mL}, 1$ vol\% inoculation), followed by incubation at $30^{\circ} \mathrm{C}$ with rotary shaking for $48 \mathrm{~h}$ (preculture). Cells in the preculture were collected by centrifugation $(3,000 \times \mathrm{g}, 12 \mathrm{~min})$, resuspended in the same amount of fresh culture medium with cellulase and antibiotics, and grown under the shaking conditions (main culture; high-density culture). Cell growth was monitored every $24 \mathrm{~h}$ by measuring OD600 values of three individual flasks. The OD600 values were converted into cell

dry weight per volume $\left(\mathrm{g}_{\mathrm{cdw}} / \mathrm{L}\right)$ based on calibration curves prepared by measuring both $\mathrm{g}_{\mathrm{cdw}} / \mathrm{L}$ and OD600 values for each strain.

\section{Preparation of Hyaluronan from a Culture Broth}

Hyaluronan (HA) in the culture broth was extracted and purified using the following procedure.

First, culture broth of $\mathrm{Gh}(\mathrm{HA})(2 \mathrm{~L})$, grown at $30^{\circ} \mathrm{C}$ under shaking conditions $(125 \mathrm{rpm})$ for $72 \mathrm{~h}$, was freeze-dried. To the lyophilized broth was added $0.25 \mathrm{M} \mathrm{MgCl}_{2}$ solution, followed by 
incubation at $4{ }^{\circ} \mathrm{C}$ until solubilized, and then 3 volumes of $4{ }^{\circ} \mathrm{C}$ ethanol (99.5\%) was added. After thorough mixing, the resulting mixture was centrifuged to separate precipitates containing HA from the supernatant. The water-soluble fraction was extracted with distilled water from the precipitates, then separated by centrifugation $(14,000 \times \mathrm{g}, 10-15 \mathrm{~min})$. HA was precipitated by adding an equal volume of $2 \%(\mathrm{w} / \mathrm{v})$ cetyltrimethylammonium bromide (CTAB) solution to the supernatant, and further extracted with $0.25 \mathrm{M} \mathrm{MgCl}_{2}$ solution from the precipitated insoluble CTA (cetyltrimethylammonium) complex ${ }^{9}$. The purified HA sample solution was used for NMR and SEC measurements.

\section{Nuclear Magnetic Resonance (NMR) Spectroscopy}

HA samples prepared using the above method and commercial sodium hyaluronate (FCH-60) were treated with hyaluronidase (Type II, ECN 3.2.1.35; final concentration, $1.0 \mathrm{mg} / \mathrm{mL}$ ) at $37{ }^{\circ} \mathrm{C}$ for $48 \mathrm{~h}$. The digested HA fragments were purified with 5\% (w/v) trichloroacetic acid (TCA) and diethyl ether, followed by ethanol precipitation. Purified HA fragment samples were dissolved in $\mathrm{D}_{2} \mathrm{O}$ (final concentration, $\sim 15 \mathrm{mg} / \mathrm{mL}$ ) and incubated for more than $12 \mathrm{~h}$ at $4{ }^{\circ} \mathrm{C}$ before

measurements. ${ }^{13} \mathrm{C}$ NMR measurements were performed using a JNM-ECZ400S spectrometer 
(JEOL Ltd.) at $400 \mathrm{MHz}$ with a single pulse decoupled gated nuclear Overhauser effect (NOE) at

$22-23{ }^{\circ} \mathrm{C}$. The spectrum was recorded by collecting 9,216 scans of 32,768 data points with an acquisition time of $1.03809 \mathrm{~s}$ and relaxation delay of $2 \mathrm{~s}$. The reported chemical shifts are with reference to sodium 3-(trimethylsilyl)propionate-2,2,3,3-d4.

\section{Size-Exclusion Chromatography (SEC)}

The purified HA sample extracted from $\mathrm{Gh}(\mathrm{HA})$ culture was precipitated, then dissolved in 0.1

M sodium nitrate solution ( $\mathrm{pH} 7.0$ ) at $1.0 \mathrm{mg} / \mathrm{mL}$, and incubated for more than $24 \mathrm{~h}$ at $4{ }^{\circ} \mathrm{C}$ before measurements. Size-exclusion chromatography was performed on a high-performance liquid chromatography system (HPLC) (JASCO Inc.) equipped with an RI-930 detector. HA separation was achieved using Shodex Ohpak SB-803HQ and Shodex Ohpak SB-802.5HQ columns (Showa Denko K.K.) in series. The columns were kept in a column oven at $40{ }^{\circ} \mathrm{C}$. The mobile phase used was $0.1 \mathrm{M}$ sodium nitrate solution ( $\mathrm{pH} 7.0$ ). The flow rate was set at $0.5 \mathrm{~mL} / \mathrm{min}$, and $50 \mu \mathrm{L}$ of the sample solutions was injected using an autosampler (JASCO AS-2057). Data acquisition and calculations were performed using a JASCO ChromNav software. Pullulan (Shodex STANDARD P-82, Showa Denko K.K.) was chosen as the standard to prepare a calibration curve. The HA peak 
was identified by confirming the peak dissipation when treated with hyaluronidase $(1.0 \mathrm{mg} / \mathrm{mL})$

at $37^{\circ} \mathrm{C}$ for $48 \mathrm{~h}$.

\section{Quantitative HA Assay}

HA in the Gh(HA) main culture broth (high-density culture) was extracted after each 24 h period of the culture time $(0-168 \mathrm{~h})$ using the method of Mao and Chen ${ }^{10}$ with modifications. First, one volume of $2 \%(\mathrm{w} / \mathrm{v})$ CTAB solution was added to the culture broth $(2.5 \mathrm{~mL})$, followed by incubation for $48 \mathrm{~h}$ at $37{ }^{\circ} \mathrm{C}$ to generate CTA complex as a precipitate. After separation by centrifugation, acidic polysaccharides containing HA in the precipitates were extracted with $1 \mathrm{M}$ $\mathrm{NaCl}$ solution $(300 \mu \mathrm{L})$. Residual CTAB in the extract was removed by ethanol precipitation. The water-soluble fraction was extracted from the precipitate using distilled water $(500 \mu \mathrm{L})$. The HA content was quantified by interpreting the absorbance at $520 \mathrm{~nm}$ measured with DU730 UV/vis spectrometer (Beckman Coulter Inc., CA, USA), which represents the concentration of glucuronic acid released by $\mathrm{H}_{2} \mathrm{SO}_{4}$ hydrolysis, using the method of Blumenkrantz and Gustav ${ }^{11}$ with 3phenylphenol. Commercial sodium hyaluronate (FCH-60) was used as the standard for calibration 
throughout this paper. Therefore we have termed the results as "HA concentration" or "HA yield", instead of "uronic acid concentration" or "uronic acid yield".

\section{Confocal Laser Scanning Microscopy (CLSM)}

G. hansenii transformants were grown at $30^{\circ} \mathrm{C}$ for $48-72 \mathrm{~h}$ in $\mathrm{HS}$ medium supplemented with cellulase $(0.1 \%, \mathrm{w} / \mathrm{v})$ and appropriate antibiotics under shaking conditions (175 strokes/min). $E$. coli transformants having pmhas and ugd genes (the same gene set as Gh(HA) was introduced) were grown at $37^{\circ} \mathrm{C}$ for $48-72 \mathrm{~h}$ in $\mathrm{LB}$ broth supplemented with appropriate antibiotics under shaking conditions (250 rpm). A coverslip coated with poly-L-lysine was used as the substrate for observation. Gh and cells in a culture were collected by centrifugation, washed once or twice with fresh HS media to remove cellulase, and resuspended in the same volume of fresh HS medium. $E$. coli cells were collected by centrifugation, washed twice with fresh LB broth, and resuspended in

fresh medium and diluted. A small portion of cell suspension was dropped on the coverslip and incubated for $15 \mathrm{~min}$ at $25^{\circ} \mathrm{C}$. After incubation, the coverslip was washed with PBS once, and then treated with $2 \%(\mathrm{w} / \mathrm{v})$ glutaraldehyde-PBS solution for $15 \mathrm{~min}$ for chemical fixation of the cells. The coverslip was treated with 3\% (w/v) bovine serum albumin in PBS (blocking) and then 
stained with biotinylated hyaluronan binding protein (HABP) $(0.25 \mu \mathrm{g} / \mathrm{mL}$, HOKUDO Co., Ltd),

iFluor 546-streptavidin conjugate (iFluor546) $(0.2 \mu \mathrm{g} / \mathrm{mL}$, AAT Bioquest Inc.), and calcofluor white M2R (CW) (10 $\mu \mathrm{g} / \mathrm{mL}$, Sigma-Aldrich). HABP together with iFluor546 and CW successfully stain produced HA and cellulose, respectively. After staining, the samples were enclosed on a glass slide with a drop of ProLong Antifade Reagent (Thermo Fisher Scientific Inc.).

In vivo and In situ $\mathrm{HA} / \mathrm{BC}$ pellicles and native $\mathrm{BC}$ pellicles obtained from $G$. hansenii stationary culture were purified using a method described later. Small pieces of the samples were cut from never-dried pellicles with scissors and placed onto glass slides. These samples were air-dried in an oven $\left(50^{\circ} \mathrm{C}\right)$ for $12 \mathrm{~h}$ to become attached to the glass substrates before staining. HA and BCspecific staining was conducted using the same method as described above. More careful operation was required in the washing steps to remove excess staining reagents from the pellicles.

Microscope observation was conducted by confocal laser scanning microscopy (CLSM) (Leica SP8, Leica Microsystems $\mathrm{GmbH}$ ). The laser settings for excitation wavelength $\lambda_{\mathrm{ex}}$ ) and the detection wavelength $\left(\lambda_{\mathrm{em}}\right)$ range for each fluorophore were as follows: iFluor $546\left(\lambda_{\mathrm{ex}}, 541 \mathrm{~nm}\right.$; $\left.\lambda_{\mathrm{em}}, 550-570 \mathrm{~nm}\right), \mathrm{CW}\left(\lambda_{\mathrm{ex}}, 405 \mathrm{~nm} ; \lambda_{\mathrm{em}}, 430-470 \mathrm{~nm}\right)$, EGFP $\left(\lambda_{\mathrm{ex}}, 489 \mathrm{~nm} ; \lambda_{\mathrm{em}}, 500-520 \mathrm{~nm}\right)$, and mCherry $\left(\lambda_{\mathrm{ex}}, 587 \mathrm{~nm} ; \lambda_{\mathrm{em}}, 610-625 \mathrm{~nm}\right)$. The images were processed using LAS X software 
(Leica Microsystems). Projection images were obtained by integrating Z-stack sequence images in CLSM using LAS X.

\section{Pellicle Production and Purification}

G. hansenii transformants were grown in two steps (preculture and main culture). The seed culture was inoculated into HS medium supplemented with cellulase $(0.1 \%, \mathrm{w} / \mathrm{v})$ and appropriate antibiotics, and then grown under shaking conditions $(125 \mathrm{rpm})$ (preculture). The preculture was grown for 5 days in total, with medium exchange conducted after the first $48 \mathrm{~h}$ period. Cells in the preculture were pelleted by centrifugation $(3,000 \times \mathrm{g}, 12 \mathrm{~min})$, resuspended in fresh medium without cellulase (main culture), and then grown statically for 36 or $72 \mathrm{~h}$ to produce cellulose membrane (pellicle). In situ $\mathrm{HA} / \mathrm{BC}$ pellicles were produced by adding sodium hyaluronate to the $\mathrm{Gh}(\mathrm{pTI} 99)$ main culture at a final HA concentration of $0.5 \%(\mathrm{w} / \mathrm{v})$.

The pellicles were purified using a sequence of enzymatic treatment (K. Matsushita et al. 1981) ${ }^{12}$ and $\mathrm{NaOH} /$ sodium dodecyl sulfate (SDS) treatment (Appendix 1). The pellicles were first treated with $0.1 \%$ (w/v) SDS, then lysozyme solution (final concentration, $50-100 \mu \mathrm{g} / \mathrm{mL}$ ) at $4{ }^{\circ} \mathrm{C}$ for at least $3 \mathrm{~h}$, followed by $50{ }^{\circ} \mathrm{C}$ for $5 \mathrm{~min}$, and then immersed in $0.1 \%(\mathrm{w} / \mathrm{v}) \mathrm{NaOH}$ solution at $25^{\circ} \mathrm{C}$ 
for $1 \mathrm{~h}$. The pellicles were then immersed in deionized water until the $\mathrm{pH}$ was neutral. The removal of bacterial cells was confirmed by FE-SEM observation. The purified pellicles were freeze-dried or air-dried depending on the subsequent experiments. The pellicle yields were calculated based on the culture volume and weight of the lyophilized pellicles.

\section{Field-Emission Scanning Electron Microscopy (FE-SEM)}

Purified pellicles were freeze-dried on an SEM grid and coated with osmium (thickness, $2.5 \mathrm{~nm}$ ) using an HPC-1SW instrument (Vacuum Device Co.). FE-SEM observation was conducted using an SU8000 instrument (Hitachi High-Tech Inc.) at an accelerating voltage of $1.0 \mathrm{kV}$ and working distance of $5.8 \mathrm{~mm}$. The air-side (side facing air during static cultivation) of pellicles was observed. The images were analyzed using ImageJ/Fiji software (W. Rasband, National Institutes of Health). The operations were conducted manually without macros. Particles in the binary images were selected as pores and then the areas were measured. The pores were fitted with ellipses using ImageJ software. The major and minor axes of the fitted ellipses were measured to estimate pore sizes. Data are expressed as means \pm standard deviation (SD). Datasets were compared statistically between groups using the Steel-Dwass test, with $p<0.05$ considered statistically significant $(*)$. 


\section{Fourier-Transform Infrared Spectroscopy (FT-IR)}

Purified pellicles were placed on a polytetrafluoroethylene (PTFE) substrate and air-dried to remove water at $50^{\circ} \mathrm{C}$ for $48-72 \mathrm{~h}$, then dried under vacuum at $50^{\circ} \mathrm{C}$ for $48 \mathrm{~h}$. Commercial sodium hyaluronate was dissolved in $1 \mathrm{M} \mathrm{NaCl}$ solution and precipitated by ethanol. The precipitated $\mathrm{HA}$ was rinsed once with $75 \mathrm{vol} \%$ ethanol and then dissolved in water at $0.01 \%(\mathrm{w} / \mathrm{v})$. The HA water solution was dropped onto a PTFE substrate and air-dried at $50{ }^{\circ} \mathrm{C}$ for $48-72 \mathrm{~h}$, then dried under vacuum at $50{ }^{\circ} \mathrm{C}$ for $48 \mathrm{~h}$ to give a transparent thin film of pure HA. FT-IR spectra of the dried pellicles and pure HA films were measured using an FT/IR-6700 spectrophotometer (JASCO Inc.) equipped with a TGS detector. Measurements were performed using 64 scans with a $2 \mathrm{~cm}^{-1}$ resolution over the wavenumber range of $4000-400 \mathrm{~cm}^{-1}$. The spectra were normalized using the band at $1162 \mathrm{~cm}^{-1}$, corresponding to $\mathrm{C}-\mathrm{O}$ stretching in the glycosidic bond.

\section{Additional Treatments of Pellicles}

Purified pellicles were treated using three different methods under static conditions, as follows:

(i) $\mathrm{NaOH}\left(0.1 \%\right.$, w/v) treatment at $25{ }^{\circ} \mathrm{C}$ for $0,24,48$, and $192 \mathrm{~h}$; (ii) $\mathrm{NaOH}(0.1 \%$, w/v) treatment 
at $50{ }^{\circ} \mathrm{C}$ for 0,2 , and $4 \mathrm{~h}$; (iii) hyaluronidase $(1 \mathrm{mg} / \mathrm{mL})$ treatment at $37^{\circ} \mathrm{C}$ for 0,6 , and $12 \mathrm{~h}$. After treatment, the pellicles were washed with distilled water at $25{ }^{\circ} \mathrm{C}$ and subjected to FT-IR measurement using the method described above.

\section{Wide-Angle X-ray Diffraction (WAXD)}

The crystalline structure of the secreted BNC fibers in the freeze-dried pellicles was studied by wide-angle x-ray diffraction (WAXD) using a MiniFlex600-C diffractometer (Rigaku Co. Ltd.). $\mathrm{Cu} \mathrm{Ka}$ radiation was produced at $40 \mathrm{kV}$ and $15 \mathrm{~mA}$. Scans were obtained in the $5-60^{\circ}$ diffraction range using steps of $0.01^{\circ}$. Four crystalline peaks and one amorphous peak were separated by deconvolution based on the Gaussian function using GRAMS/AI software (Thermo Fischer Scientific Inc.). Crystallinity was determined by subtracting the amorphous contribution from diffraction spectra.

\section{Supporting Data}

\section{Statistical analysis}

All statistical analyses were performed using R software (The R Foundation). 


\section{Supporting Figures}

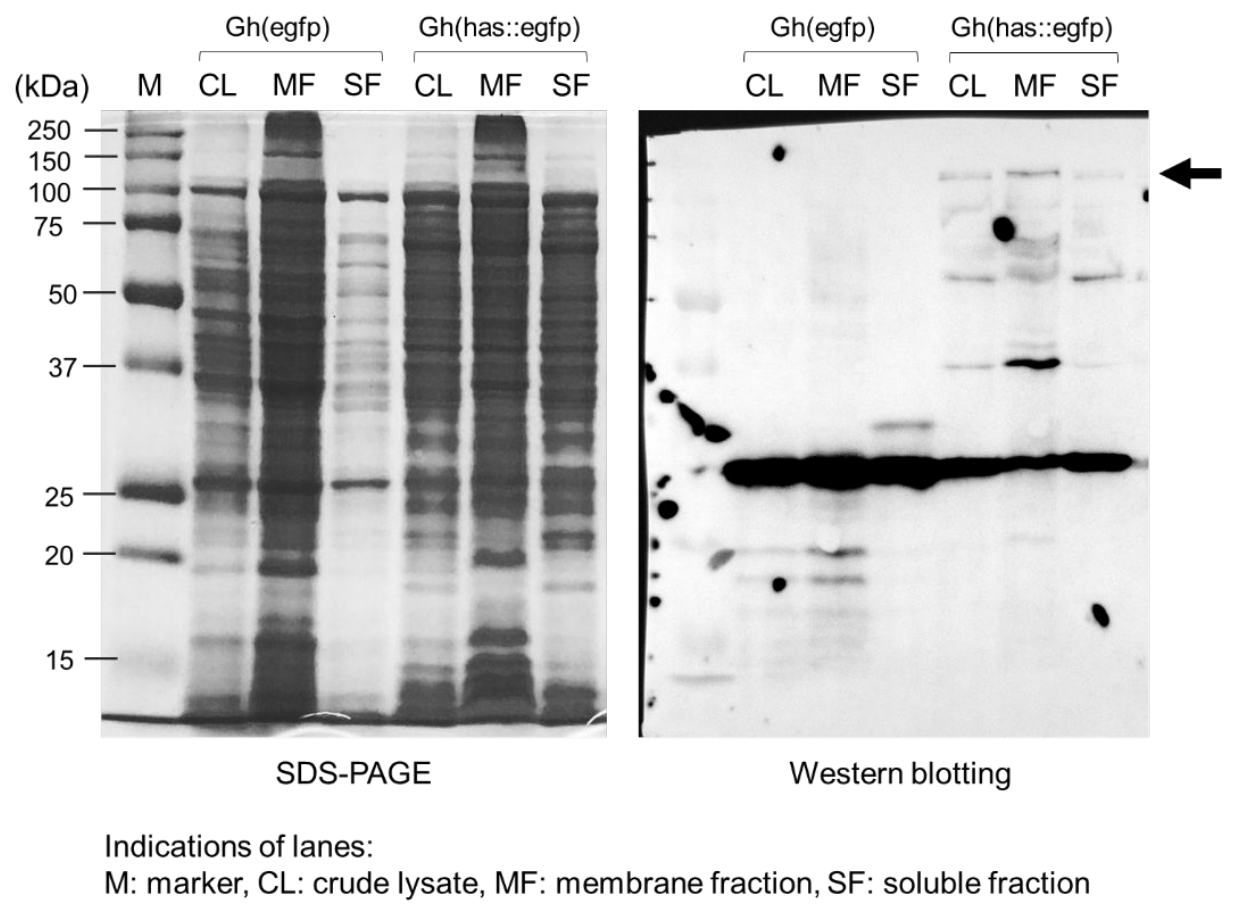

Fig. S1 Confirmation of PmHAS protein expression by western blot analysis using C-terminal

EGFP-tagged PmHAS and an anti-EGFP antibody

Black arrow indicates the protein bands (approximately $140 \mathrm{kDa}$ ) which is considered as

EGFP-tagged PmHAS. The molecular mass of PmHAS is estimated to be $\sim 110 \mathrm{kDa}^{13}$ and that of

EGFP is $27 \mathrm{kDa}^{14}$. This result suggests that PmHAS can be expressed in Gh. 

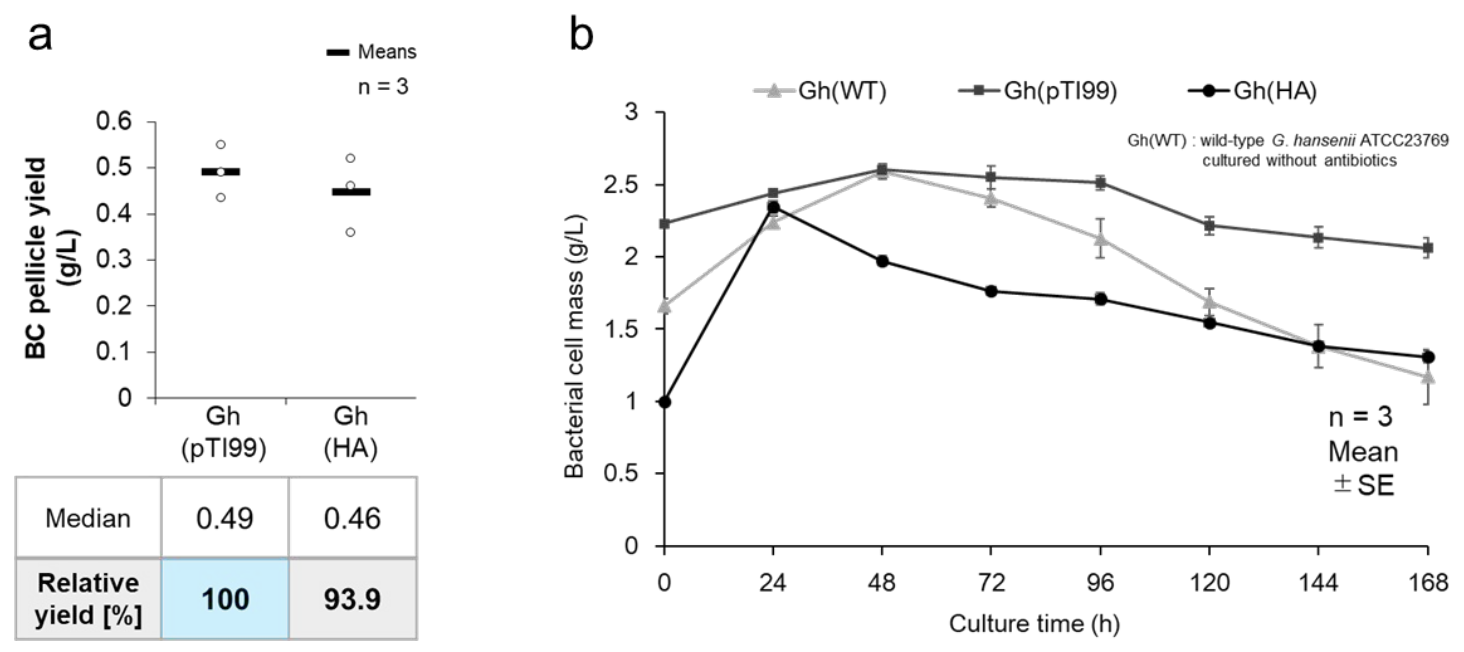

Fig. S2 BC yields and growth curves

a BC pellicle yields of engineered $G$. hansenii $(\mathrm{Gh}(\mathrm{HA}))$ and the standard strain $(\mathrm{Gh}(\mathrm{pTI} 99))$. b

Bacterial cell mass of $G$. hansenii strains during main culture (high-density culture).

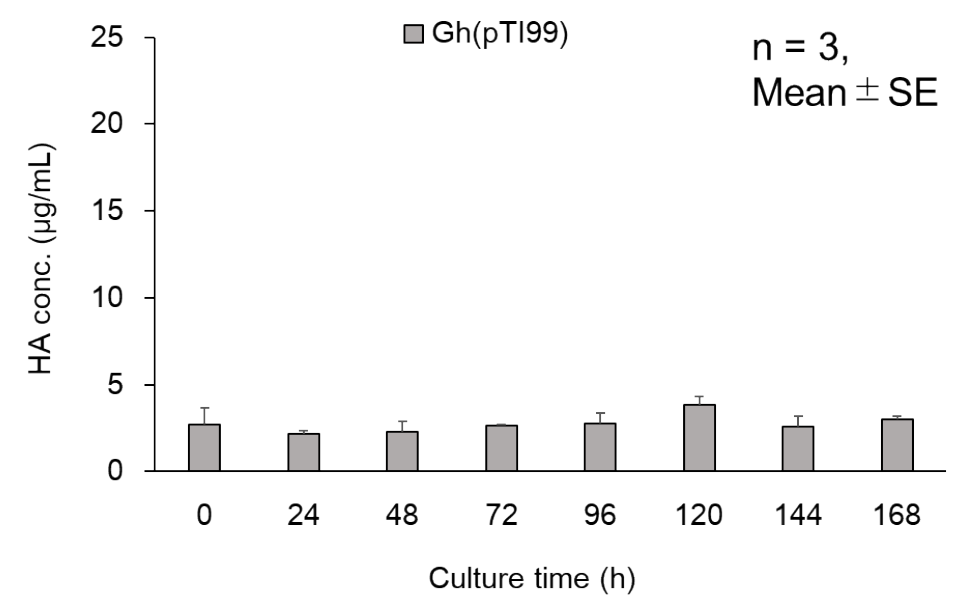

Fig. S3. HA concentrations of samples prepared from culture broth (main culture: high-density culture) of Gh(pTI99)

The average value $=2.75 \pm 0.18 \mu \mathrm{g} / \mathrm{mL}$. 


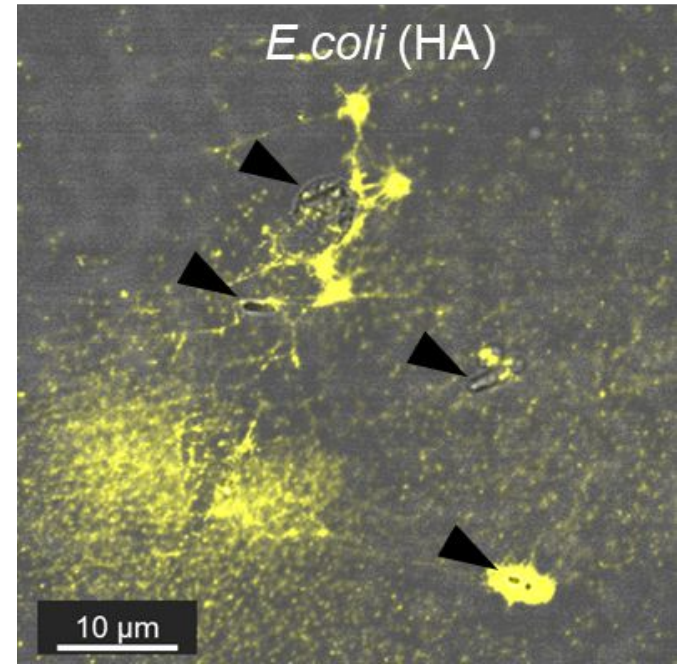

Fig. S4. CLSM image of the engineered E. coli

This is a CLSM image of E. coli having the same gene set of pmhas and ugd(E.coli (HA)) as

Gh(HA), loaded onto the PLL-coated glass substrate. This CLSM image of the engineered

Escherichia coli is considered as a control, which secretes HA but BC nanofibrils. HA was

stained with HABP containing iFluor546 (Yellow). Black arrowheads indicate cells secreting a

HA. 

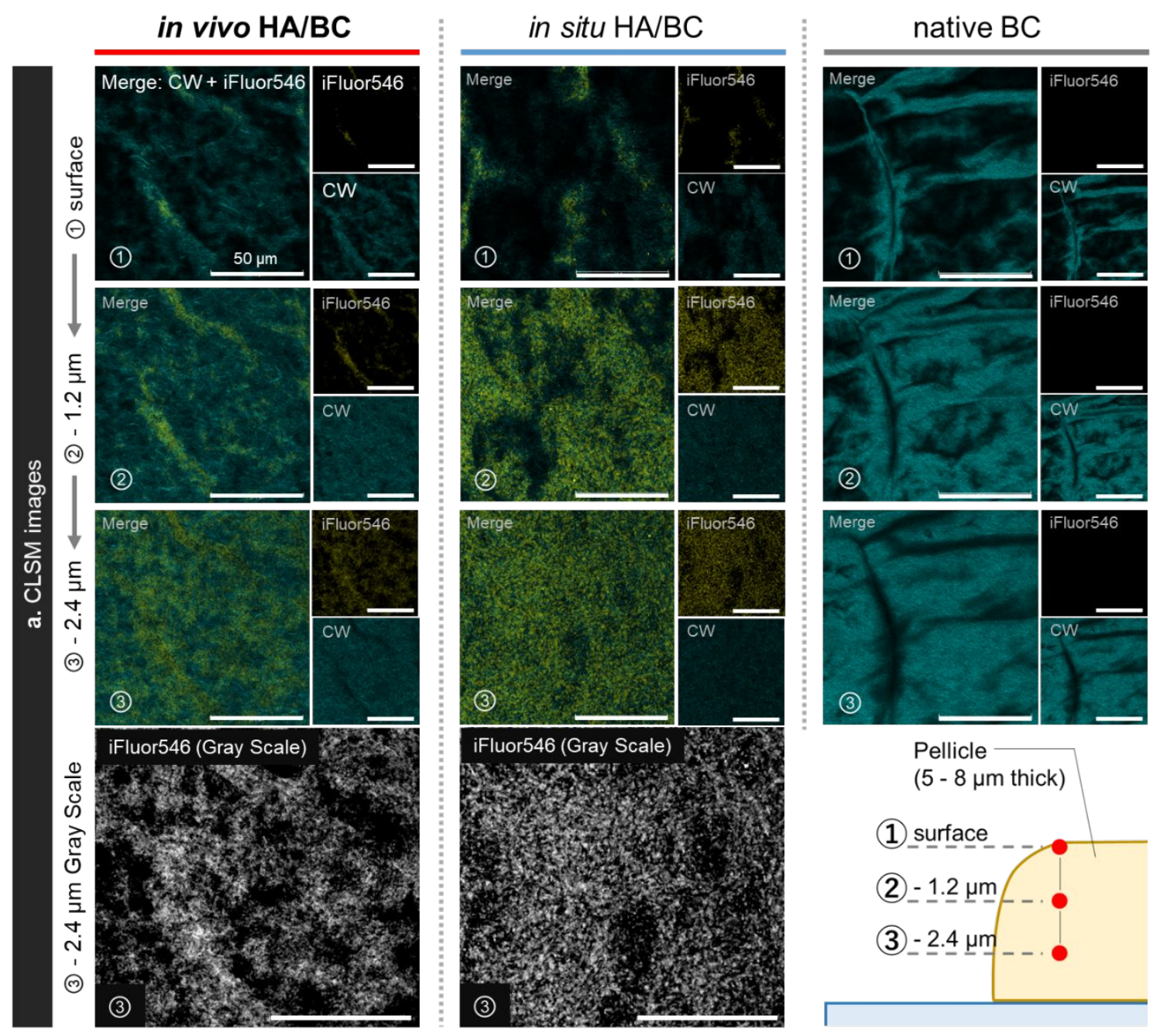

Pellicle

(5 - $8 \mu \mathrm{m}$ thick)

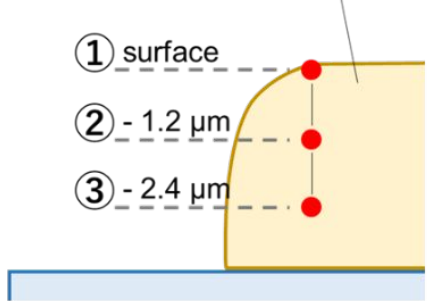

in vivo $\mathrm{HA} / \mathrm{BC}$

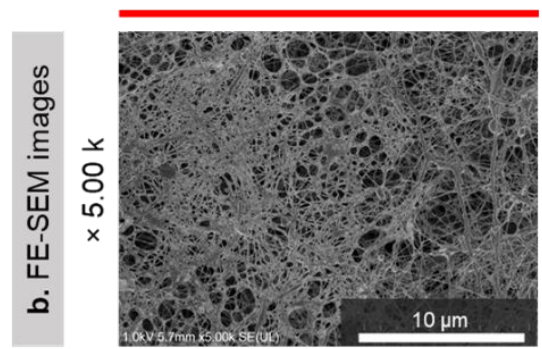

in situ $\mathrm{HA} / \mathrm{BC}$
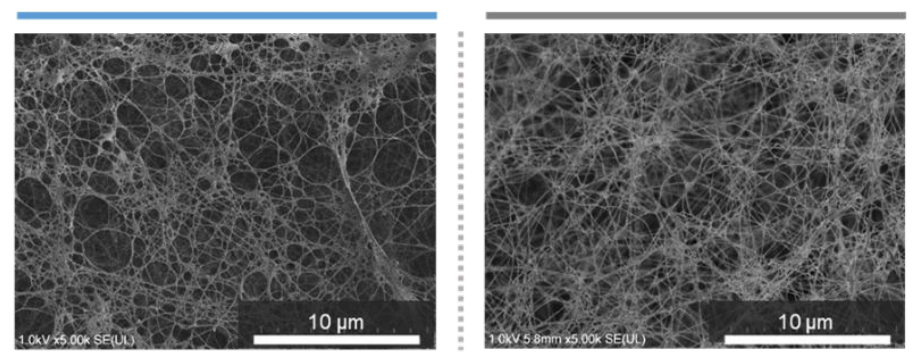

native $B C$
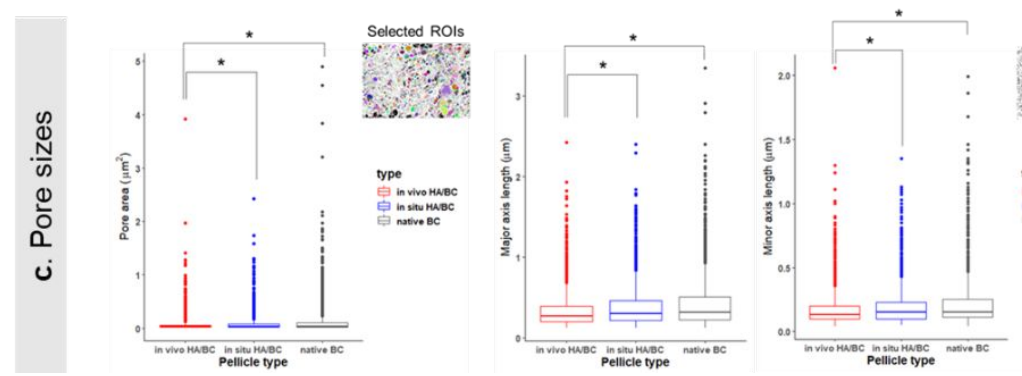

\begin{tabular}{|l:l|}
\hline \multicolumn{2}{|l|}{ Group sizes: } \\
\hline in vivo HA/BC & $n=2137$ \\
in situ HA/BC & $n=2070$ \\
native $B C$ & $n=1540$ \\
\hline
\end{tabular}

type
Pin vivo HuBc
in inu HuBC

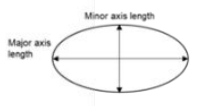


Fig. S5. CLSM images and analytical data. a CLSM images of pellicles produced by three different processes. Images were captured at three constant $z$-positions (1): $z=0$, the pellicle surface; (2): $z$ $=-1.2 \mu \mathrm{m}$, beneath (1); (3): $z=-2.4 \mu \mathrm{m}$, beneath (1)) for each $x-y$ position. HA was stained by HABP with iFluor546 (yellow). BC was stained with CW (blue). Grayscale images were produced from images of iFluor546 channels applied with 8-bit conversion and contrast stretch (normalization) using ImageJ. $\mathbf{b}$ FE-SEM images of freeze-dried pellicles. $\mathbf{c}$ Measurements of pore size indicators on pellicle surfaces by FE-SEM image analysis. Pores were selected (in vivo $\mathrm{HA} / \mathrm{BC}, \mathrm{n}=2137$; in situ $\mathrm{HA} / \mathrm{BC}, \mathrm{n}=2070$; native $\mathrm{BC}, \mathrm{n}=1540$ ), and the pore areas were measured (left) and fitted with ellipses using ImageJ. The major and minor axes of the fitted ellipses were measured as values estimating pore size (right). Datasets were evaluated statistically using the Steel-Dwass test, with $p<0.05$ considered statistically significant $(*)$. 


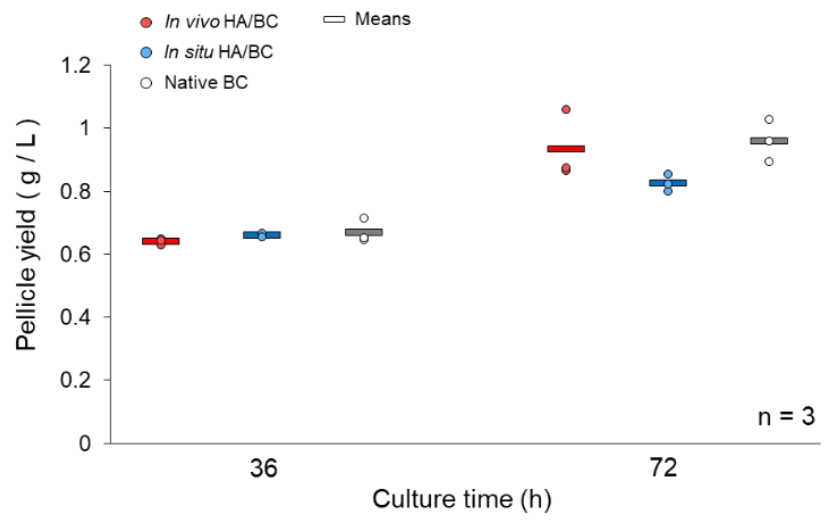

Fig. S6. Pellicle yields in the stationary culture after periods of 36 and $72 \mathrm{~h}$. 


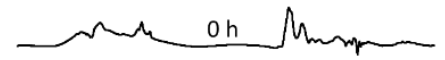

0.1 (w/v) \% $\mathrm{NaOH}$

$25^{\circ} \mathrm{C}$
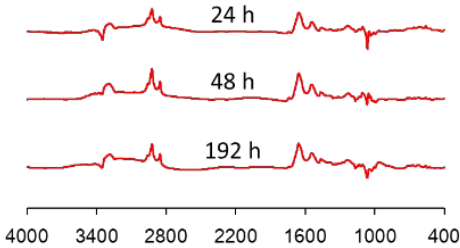

$\begin{array}{lllllll}4000 & 3400 & 2800 & 2200 & 1600 & 1000 & 400\end{array}$ b

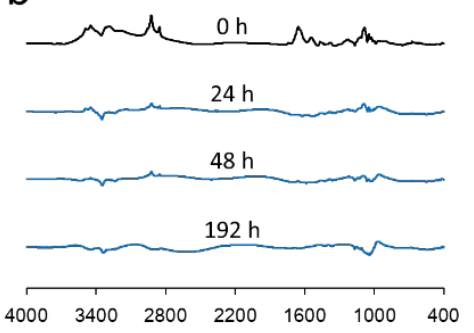

d

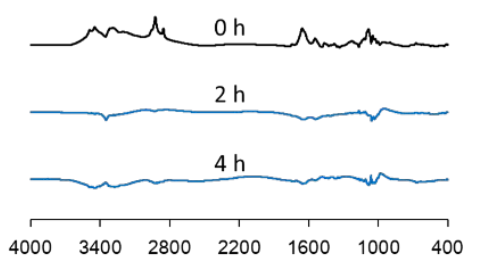

$\begin{array}{lllllll}4000 & 3400 & 2800 & 2200 & 1600 & 1000 & 400\end{array}$
Hyaluronidase

(1 $\mathrm{mg} / \mathrm{mL}$ )

$37^{\circ} \mathrm{C}$
C

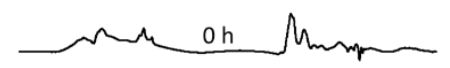

0.1 (w/v) $\% \mathrm{NaOH}$

$50{ }^{\circ} \mathrm{C}$

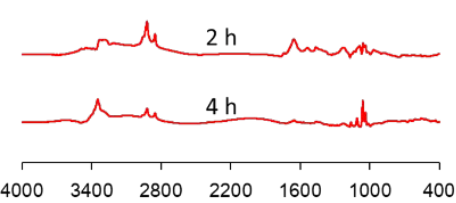

\section{e}

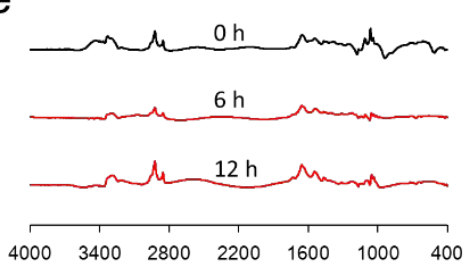

f

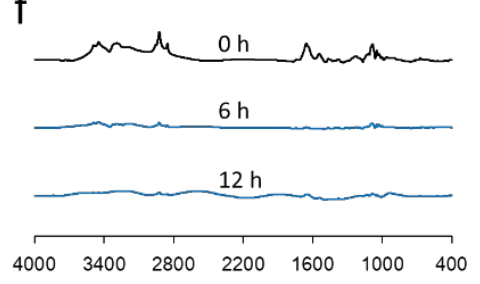

Fig. S7. Effect of additional treatments on FT-IR difference spectra of in vivo and in situ HA/BC

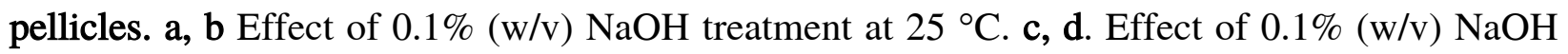
treatment at $50{ }^{\circ} \mathrm{C}$. e, f Effect of hyaluronidase $(1 \mathrm{mg} / \mathrm{mL})$ treatment at $37^{\circ} \mathrm{C}$. Spectra were obtained by subtracting native $\mathrm{BC}$ spectra from those of in vivo $\mathrm{HA} / \mathrm{BC}(\mathrm{a}, \mathrm{c}, \mathrm{e})$ or in situ $\mathrm{HA} / \mathrm{BC}$ $(b, d, f)$. 
Table S1. Bacterial strains, genes, plasmids, and primers used in this study.

\begin{tabular}{|c|c|c|}
\hline Name & Descriptions : Relevant characteristics, genotype, or sequence & Source \\
\hline \multicolumn{3}{|l|}{ Strains } \\
\hline Gluconacetobacter hansenii ATCC23769 & Wild-type, cellulose producing strain & ATCC \\
\hline Escherichia coli JM109 & $\begin{array}{l}\text { recA1, endA1, gyrA96, thi, hsdR17(rK-mK+), e14-(mcrA-), supE44, relA1, } \Delta \text { (lac-proAB) / F' [traD36, proAB+, laclq, lacZ } \\
\Delta \mathrm{M} 15]\end{array}$ & TaKaRa \\
\hline Escherichia coli HST08 & $\begin{array}{l}\text { F-, endA1, supE44, thi-1, recA1, relA1, gyrA96, phoA, } \$ 80 \text { dlacZ } \Delta M 15, \Delta(\text { lacZYA-argF)U169, } \Delta \text { (mr-hsdRMS-mcrBC), } \\
\Delta \text { mcrA, } \lambda \text { - }\end{array}$ & TaKaRa \\
\hline \multicolumn{3}{|l|}{ Genes } \\
\hline pmhas (2920 bp) & hyaluronan synthase gene derived from Pasteurella multocida ATCC15742 genomic DNA. & ATCC \\
\hline $\operatorname{ugd}(1314 \mathrm{bp})$ & UDP-glucose dehydrogenase gene derived from Shinorhizobium meliloti 1021 genomic DNA. & ATCC \\
\hline \multicolumn{3}{|l|}{ Plasmids } \\
\hline pTI99 & pTrc99A derivative: replication gene from $A$. xylinum IFO3288, E. coli - G. hansenii shuttle vector & Hu et al. 2010 \\
\hline pTI99-pmhas & pT199 derivative : pmhas & This study \\
\hline PTIHA & pT199 derivative : pmhas, ugd & This study \\
\hline pTIEK & pTI99 derivative : egfp, Kanamycin resistant gene (KanR) & Sunagawa et al. 2013 \\
\hline pTIEK-pmhas.:egfp & pTI99 derivative : pmhas.:egfp, KanR & This study \\
\hline Primers & sequence $\left(5^{\prime}-3^{\prime}\right)$ & \\
\hline $\mathrm{SP}($ pmhas $)$ & CAGACCATGGAATTCATGAATACATTATCACAAGCAATAAAAG & This study \\
\hline $\mathrm{AP}($ pmhas $)$ & GTTTCCTGGATCCTTTATACTATTAATAATGAACTTGTT & This study \\
\hline $\mathrm{SP}(u g d)$ & $\begin{array}{l}\text { CTCTATAAAGGATCCTTGACAATTAATCATCCGGCTCGTATAATGAGCTCAATTGTGAGCGATAACAATTGAGCTCAGGAAAC } \\
\text { AGACCATGAAAATCAC }\end{array}$ & This study \\
\hline $\mathrm{AP}(u g d)$ & TGCCTGCAGGTCGACTCAGTCCGGCCTGCC & This study \\
\hline $\mathrm{AP}($ pmhas::egfp $)$ & GCTCACCATGGATCCTAGAGTTATACTATTAATAATGAACTTGTTAAC & This study \\
\hline
\end{tabular}

\section{Appendix. Pellicle purification method}

\section{Materials}

$0.1 \%(w / v)$ SDS water solution

Solution I (100 mM NaCl, 20 mM Tris-HCl, 2 mM EDTA, Lysozyme (50-100 $\mu \mathrm{g} / \mathrm{mL}))$

Solution II (20 mM Tris-HCl, 5 mM MgCl 2 , Lysozyme (50-100 $\mu \mathrm{g} / \mathrm{mL})$, benzonase (25 U/mL))

$0.1 \%(w / v) \mathrm{NaOH}$ water solution

\section{Methods}


Wash pellicles with distilled water several times.

Immerse pellicles in $0.1 \%(\mathrm{w} / \mathrm{v}) \mathrm{SDS}$ water solution and leave at $25{ }^{\circ} \mathrm{C}$ for $30 \mathrm{~min}$.

Wash pellicles with distilled water at $25^{\circ} \mathrm{C}$ for $1 \mathrm{~h}$.

Immerse pellicles in solution I and store at $4{ }^{\circ} \mathrm{C}$ for $3-12 \mathrm{~h}$.

Heat pellicles in solution I in a water bath at $50{ }^{\circ} \mathrm{C}$ for $5 \mathrm{~min}$.

Wash pellicles with distilled water several times.

Immerse pellicles in solution II and store at $4{ }^{\circ} \mathrm{C}$ for $3-12 \mathrm{~h}$.

Heat pellicles in solution II in a water bath at $50{ }^{\circ} \mathrm{C}$ for $5 \mathrm{~min}$.

Wash pellicles with distilled water several times.

Immerse pellicles in $0.1 \%(\mathrm{w} / \mathrm{v}) \mathrm{NaOH}$ water solution and leave at $25^{\circ} \mathrm{C}$ for $1 \mathrm{~h}$.

Wash pellicles with distilled water until the $\mathrm{pH}$ is neutral.

\section{References}

(1) Deangelis, P. L.; Jing, W.; Drake, R. R.; Achyuthan, A. M. Identification and Molecular

Cloning of a Unique Hyaluronan Synthase from Pasteurella Multocida*, 1998.

https://doi.org/10.1074/jbc.273.14.8454. 
(2) Capela, D.; Barloy-Hubler, F.; Gouzy, J.; Bothe, G.; Ampe, F.; Batut, J.; Boistard, P.;

Becker, A.; Boutry, M.; Cadieu, E.; Dréano, S.; Gloux, S.; Godrie, T.; Goffeau, A.; Kahn,

D.; Kiss, E.; Lelaure, V.; Masuy, D.; Pohl, T.; Portetelle, D.; Pühler, A.; Purnelle, B.;

Ramsperger, U.; Renard, C.; Thébault, P.; Vandenbol, M.; Weidner, S.; Galibert, F.

Analysis of the Chromosome Sequence of the Legume Symbiont Sinorhizobium Meliloti

Strain 1021. Proc. Natl. Acad. Sci. U. S. A. 2001, $98(17), 9877-9882$.

https://doi.org/10.1073/pnas.161294398.

(3) Galibert, F.; Finan, T. M.; Long, S. R.; Pühler, A.; Abola, P.; Ampe, F.; Barloy-Hubler,

F.; Barnet, M. J.; Becker, A.; Boistard, P.; Bothe, G.; Boutry, M.; Bowser, L.; Buhrmester,

J.; Cadieu, E.; Capela, D.; Chain, P.; Cowie, A.; Davis, R. W.; Dréano, S.; Federspiel, N.

A.; Fisher, R. F.; Gloux, S.; Godrie, T.; Goffeau, A.; Golding, B.; Gouzy, J.; Gurjal, M.;

Hernandez-Lucas, I.; Hong, A.; Huizar, L.; Hyman, R. W.; Jones, T.; Kahn, D.; Kahn, M.

L.; Kalman, S.; Keating, D. H.; Kiss, E.; Komp, C.; Lelaure, V.; Masuy, D.; Palm, C.;

Peck, M. C.; Pohl, T. M.; Portetelle, D.; Purnelle, B.; Ramsperger, U.; Surzycki, R.;

Thébault, P.; Vandenbol, M.; Vorhölter, F. J.; Weidner, S.; Wells, D. H.; Wong, K.; Yeh, 
K. C.; Batut, J. The Composite Genome of the Legume Symbiont Sinorhizobium Meliloti.

Science (80-. ). 2001, 293 (5530), 668-672. https://doi.org/10.1126/science.1060966.

(4) Hu, S. Q.; Gao, Y. G.; Tajima, K.; Sunagawa, N.; Zhou, Y.; Kawano, S.; Fujiwara, T.;

Yoda, T.; Shimura, D.; Satoh, Y.; Munekata, M.; Tanaka, I.; Yao, M. Structure of

Bacterial Cellulose Synthase Subunit D Octamer with Four Inner Passageways. Proc. Natl.

Acad. Sci. U. S. A. 2010, 107(42), 17957-17961.

https://doi.org/10.1073/pnas.1000601107.

(5) Sunagawa, N.; Fujiwara, T.; Yoda, T.; Kawano, S.; Satoh, Y.; Yao, M.; Tajima, K.; Dairi,

T. Cellulose Complementing Factor (Ccp) Is a New Member of the Cellulose Synthase

Complex (Terminal Complex) in Acetobacter Xylinum. J. Biosci. Bioeng. 2013, 115(6),

607-612. https://doi.org/10.1016/j.jbiosc.2012.12.021.

(6) Hall, P. E.; Anderson, S. M.; Johnston, D. M.; Cannon, R. E. Transformation of

Acetobacter Xylinum with Plasmid DNA by Electroporation. Plasmid 1992, 28 (3), 194-

200. https://doi.org/10.1016/0147-619X(92)90051-B. 
(7) Florea, M.; Hagemann, H.; Santosa, G.; Abbott, J.; Micklem, C. N.; Spencer-Milnes, X.;

De Arroyo Garcia, L.; Paschou, D.; Lazenbatt, C.; Kong, D.; Chughtai, H.; Jensen, K.;

Freemont, P. S.; Kitney, R.; Reeve, B.; Ellis, T. Engineering Control of Bacterial

Cellulose Production Using a Genetic Toolkit and a New Celluloseproducing Strain. Proc.

Natl. Acad. Sci. U. S. A. 2016, 113(24), E3431-E3440.

https://doi.org/10.1073/pnas.1522985113.

(8) HESTRIN, S.; SCHRAMM, M. Synthesis of Cellulose by Acetobacter Xylinum. II.

Preparation of Freeze-Dried Cells Capable of Polymerizing Glucose to Cellulose.

Biochem. J. 1954, 58(2), 345-352. https://doi.org/10.1042/bj0580345.

(9) Scott, J. E. Aliphatic Ammonium Salts in the Assay of Acidic Polysaccharides from

Tissues. In Methods of Biochemical Analysis, Volume 8 ; John Wiley \& Sons, Ltd, 1960;

pp 145-197. https://doi.org/10.1002/9780470110249.ch4.

(10) Mao, Z.; Chen, R. R. Recombinant Synthesis of Hyaluronan by Agrobacterium Sp.

Biotechnol. Prog. 2007, 23(5), 1038-1042. https://doi.org/10.1021/bp070113n. 
(11) Blumenkrantz, N.; Gustav, A.-H. New Method for Quantitative Determination of Uronic Acids. Anal. Biochem. 1973, 54(2), 484-489. https://doi.org/10.1016.

(12) Matsushita, K.; Shinagawa, E.; Adachi, O.; Ameyama, M. Spheroplast of Acetic Acid Bacteria. Agric. Biol. Chem. 1981, 45(6), 1515-1518.

https://doi.org/10.1080/00021369.1981.10864740.

(13) Jing, W.; De Angelis, P. L. Dissection of the Two Transferase Activities of the Pasteurella Multocida Hyaluronan Synthase: Two Active Sites Exist in One Polypeptide.

Glycobiology 2000, 10 (9), 883-889. https://doi.org/10.1093/glycob/10.9.883.

(14) Y, N.; T, I.; H, N.; J, B.; T, K.; FI, T.; S, S. Chemical Synthesis of the Precursor Molecule of the Aequorea Green Fluorescent Protein, Subsequent Folding, and Development of Fluorescence. Proc. Natl. Acad. Sci. U. S. A. 1998, 95(23), 13549-13554. https://doi.org/10.1073/PNAS.95.23.13549. 